Journal of Political Science
(A Peer-Reviewed, Open Access Journal and Indexed in NepJOL)
ISSN 2362-1273 (Print); ISSN 2773-8132 (Online)
Volume 21, Special Issue, August 2021
http://ejournals.pncampus.edu.np/ejournals/jps/
Published by
Department of Political Science, Prithvi Narayan Campus, TU, Pokhara, Nepal
Email: polsc@ @ncampus.edu.np; URL: www.pncampus.edu.np

\title{
Structural Determinants of Democratic Consolidation and Nepal's Loktantra Since 2017
}

\author{
Sanjeev Humagain, PhD \\ International Relations and Peace \\ Lumbini Buddhist University, Lumbini, Nepal
}

Corresponding Author: Dr. Sanjeev Humagain, Email: humagain_sanjeev@hotmail.com DOI: https://doi.org/10.3126/jps.v21i1.39281

Copyright 2021@ The Publisher and Author/s. The journal is licensed under a Creative Commons Attribution-ShareAlike 4.0 International License. (c) (i) ()

Submitted 19 July 2021; Reviewed 22 July 2021; Accepted 28 July 2021; Published 20 Aug. 2021

\begin{abstract}
Despite frequent political changes, democratic consolidation is not a popular question among the researchers of democracy in Nepal. This article aims to connect the theoretical discussion of consolidation of democracy, mostly focusing on the structural factors and Nepali Loktantra. Two findings of this study are particularly important for the discussion of the consolidation of Loktantra in Nepal. First, the macro structural factors - e.g., economic modernization, regime type, and party -system - make pessimistic predictions on future of Nepali democracy. In other words, the macro structural conditions are unfavorable for the consolidation of the democracy in contemporary Nepal. Second, procedural dimensions of the democracy are insufficient to define Nepali Loktantra. The newly adopted regime has attempted to merge few components of non-majoritarian democracy too. We need more critical evaluation on the characteristics of Nepali Loktantra. If it is different with a procedural democracy, its relation with socio-economic structure also should be different.
\end{abstract}

Keywords: Loktantra, structural determinants, non-majoritarian democracy, modernization

\section{Introduction}

Political change has become a regular feature of Nepali politics since 1990. The political leaderships also continuously emphasize on the institutionalization of the political change - 


\section{Women Participation in Local Development: A Study of Kaski District}

which means the democracy - always after the political change. Unlike frequent change and strong voice in politics, there are not enough academic discussions on both causes of political change and failure of the consolidation of the democracy. Whether we are practicing (and also practiced) the real democracy has become a prominent question. This article aims to bring this undiscussed question into the ring. Its more focus is in linking Nepal's democratic practice since 2017 into the theoretical debate of democratic consolidation.

Connecting our discussion of consolidation or institutionalization of democracy to the study of the comparative politics is the main goal of this article. Generally, a study of democratic consolidation has two major parts: examination of the level of consolidation and causes behind this. For example, Humagain et. al. have explained that dynastic party politics was the main causes for the failure of young parliamentary democracies - which were democratized in the third wave of democracy - in Asia (Humagain, et.al, 2020).

This study chooses a different path. It only explores how we can connect the structural factors to Nepali Loktantra. Limiting the scope to structural factors has three particular reasons. First, connect Nepali Loktantra to the mainstream discussion of comparative politics. The study of Nepali democracy often emphasizes on Nepali exceptionalism. Since 2006, the debate is excessively focused on role of ethnic, regional and cultural identity in the politics. These variables can have enough space in the structural, cultural and institutional discussion of the democratization and democratic consolidation. In other words, we do not need Nepali exceptionalism thesis to explain these dimensions. We can cover them within the structural, cultural and institutional variables. Moreover, the Nepali exceptionalism thesis completely ignores the political process. Why the democratic practice.

Bringing the general discussion of democratization and consolidation of the democracy allows us a broader understanding of present state of democracy and causes behind it. As Gasiorowski and Power have argued "the political processes that directly affect consolidation or breakdown are embedded in multifaceted social contexts that are shaped by these structural factors, which influence the character and outcomes of these processes and thus indirectly affect the likelihood that consolidation will occur" (Gasiorowski and Power, 1998, p.743). This study followed their theoretical approach.

Second, covering all dimensions of comparative politics on a research article is not a wise idea. We need several researches in micro issues. In other words, this article only aims to start this debate rather than make a final conclusion on it. Based on the statistics and findings of such works, we can have a macro discussion. Generate a consensus - that we need a more theoretical discussion on relations between level of democracy and impact of structural, institutional and other dimensions on this result - among the Nepali political scientists is also an important goal of this research. Third and finally, Nepali democracy could not become a common example in global study of the democracy. Lack of enough domestic research based on theoretical foundation is one of the main reasons. This research aims to encourage young graduate students and researchers to work more in democratic study by introducing the major theoretical discussion. We need to focus on two major dimensions. On the one hand, we need to develop broader and more comprehensive analytical framework to examine the state of democracy and causes. On the other hand, we need to focus on the operationalization and measurement of independent variables. For example, number of workers working in the industry is a major indicator in comparative democratic studies. How can we categorize around four million of Nepali people working in 


\section{Women Participation in Local Development: A Study of Kaski District}

abroad? Our theoretical and empirical discussions naturally fill the gap. The frequent discussion on Nepali democracy in global level provides us new and creative our problems.

\section{Prajatantra \& Loktantra}

Explaining democracy without using adjectives (Collier \& Levitsky1997) has become something very unnatural in the study of democracy. The term exclusion has been widely used to explain Nepal's democratic practice since 1990. In fact, their main concern was on explaining the limitations of the democracy. Scholarly attention was on exploring the ethnic (Lawoti, 2008) and political dimensions (Humagain \& Seo 2013) of exclusiveness of the Nepal's democracy. Ethnically unbalance representation - as a comprehensive outcome of formal and informal institutions - is the main concern in the former. While, later focuses party politics and party system. As Parajuli (2010) has mentioned, many studies categorized Nepali democracy as hybrid regime - "those political systems that on plausible grounds cannot be classified as either autocracy or democracy" (Bogaards, 2009).

Though Nepal is not a frequently mentioned case in global democratic research, Carothers (2002) categorized Nepal as feckless pluralism: democracy remains shallow and troubled despite significant amounts of political freedom, regular elections, and alternation of power between genuinely different political groupings (p. 10). In his popular essay, Samuel P. Huntington classified Nepal as a case of the third wave of democratization. He claimed that "the impact of the snowballing was clearly evident in 1990 in Nepal" (Huntington, 1991, p.16).

Following two decades long armed and non-armed political conflict, Nepal's Constituent Assembly promulgated new constitution in 2015 and defined Nepal's democratic system as 'loktantra.' The Nepali democracy - re-established in 1990 - was called 'prajtantra.' The academic discussion on democracy has not given enough attention comparison of these two regimes. Unlike popular discussion on the transformation of the 240-year-long unitary system to federal system, the change in democratic practice, e.g., electoral system, representation, power distribution and so forth, has not received enough attention.

Both in principle and practice, Nepal's democratic practice since 1990 has a minimalist standard - "that institutional arrangement for arriving at political decisions in which individuals acquire the power to decide by means of a competitive struggle for the people's vote" (Schumpeter,1950, p. 269). But both hardly meet the basic minimalist standard of Huntington: "most powerful collective decision makers are selected through fair, honest, and periodic elections in which candidates freely compete for votes" (Huntington, 1991, p.7). Three major approaches - inherent weakness of Nepalese politics exclusionary democratization and hybrid regime - are most widely discussed part of Nepali democracy on explaining the Nepal's failure in the consolidation of the democracy in 1990s (Humagain \& Seo 2013). The discussed inherent weaknesses of Nepali democracy were: conspiracy, mockery, nepotism, favoritism, sycophancy, Koiralaization (indicates the family politics in NC party), authoritarianism, commissionocracy, abuse of power and authority, price hikes and pollutions (Hachhethu, 1997). Another most popularly discussed issue is the frequent change of the government and factionalism within the major political parties. All major political parties splinted in 1990s and formed ten different governments in twelve years (1990-2002). Neither the phenomenon changed after 2002. Sher Bahadur Deuba sworn in as the country's $27^{\text {th }}$ prime minister in 28 years on July $13,2021$. 


\section{Women Participation in Local Development: A Study of Kaski District}

Loktantra, adopted in 2015, is a democratic regime with minimalist standard and some components of the non-majoritarian or power sharing democracy. Adoption of a bicameral federal legislative system, representation of leader of main opposition party at the constitutional council, speakers and deputy-speakers from different parties and sex, several provisions for participatory policy making and so forth are the major example of Nepal's attempt to institutionalize non-majoritarian regime. Arend Lijphart has claimed that a nonmajoritarian democracy has eight characteristics. They are :(1) executive power sharing, (2) balanced executive-legislative relations, (3) strong bicameralism, (4) multiparty system, (5) multi-dimensional party system, (6) proportional representation, (7) federalism and decentralization, and (8) a written constitution and minority veto (Lijphat, 1985, p.3). Nepali Loktantra shares many characteristics. ${ }^{1}$

Despite its non-majoritarian characteristics, it is still a democracy with minimalist standard. In other words, Nepali Loktantra has not still solved the issue raised by Larry Diamond in 2002. He claimed that "democracy requires not only free, fair, and competitive elections, but also the freedoms that make them truly meaningful (such as freedom of organization and freedom of expression), alternative sources of information, and institutions to ensure that government policies depend on the votes and preferences of citizens" (Diamond 2002, p.21). Indeed, Nepal's constitution has assured all kinds of freedom mentioned above. But neither there is enough legal arrangement to guarantee the real freedom nor the change in illiberal political practices.

Second, though Nepal has adopted several legal provisions for minority rights, we can't say it as multicultural democracy. The academic debate on multiculturism is highly centers on the experience of Western democracies. Van den Berghe argues that

[Multicultural democracy] seeks solutions to the problem of integrating disparate groups into complex, urbanised, post-industrial societies, while avoiding both the imposition of an assimilationist model based on a dominant-group definition of what the society should be, and the political expedient of disfranchising and excluding some groups from the polity and the society. It seeks to integrate without either assimilating or making official cultural differences (Van den Berghe, 2002, p. 438).

As Kymilicka has argued in several academic works, the pre-condition on rise of multiculturalism in West is entirely different from the Asian case. On the one hand, Nepal does not fit with these conditions. Very simply, "the consolidation of democracy limits the ability of elites to crush ethnic minority political movements. (Kymlicka, 2005, p.33)." Nepal is not a case of consolidation democracy. Simply, the multiculturalism in these countries becomes a solution to the problems that are not solved by a consolidated liberal democracy.

On the other hand, Nepal is in completely different path of a multicultural democracy. As Samooha argued that a "multicultural democracy acknowledges cultural differences and supports groups that organize separately, but neither legislates collective rights nor extends self-rule and power-sharing" (Samooha, 2002, p. 425). In other words, unofficial

\footnotetext{
${ }^{1}$ The non-majoritarian dimension of the democracy is a one of the major subject to be discussed in future. Particularly the we need a serious discussion on connection between non-majoritarian democracy and article 75 of Nepal's constitution.
}

Journal of Political Science, Vol. 21, Special Issue, August 2021 [11-21] 


\section{Women Participation in Local Development: A Study of Kaski District}

recognition is key component of multicultural democracy (Van den Berghe,, 2002) But the Nepali politics is in more focused on formal legalization of providing collective rights to some specific groups since 2006's second people's revolution.

In conclusion, we can claim that, though Nepali Loktantra has attempted to adopt few good theoretical and practical dimensions of non-majoritarian democracy and multiculturalism, it is still a democracy with the minimalist standard. The marriage between democracy with minimalist standard and some best practices in non-majoritarian democracy and multiculturalism, however, is not comfortable. It is creating a serious identity crisis of the whole regime.

\section{Structural Determinants of Democratic Consolidation and Loktantra}

Democratic consolidation refers to the process by which a newly established democratic regime becomes sufficiently durable that democratic breakdown - a return to nondemocratic rule - is no longer likely (Gasiorowski and Power, 1998, p. 743). Generally, we call a democracy consolidated in which democracy as a complex system of institutions, rules, and patterned incentives and disincentives has become, in a phrase "the only game in town" (Linz and Stepan, 1996, p.15). This study defines a consolidated democracy, "is a regime that meets all the procedural criteria of democracy and also in which all politically significant groups accept established political institutions and adhere to democratic rules of game" (Burton, Gunther and Higley, 1992, p.3)

The condition for consolidation of the democracy is not new topic in political science. The debate mostly accelerated after the end of Cold War. From the level of economic development to the international factor, several factors have already been discussed in academia. We can classify these discussions into two major parts: actor-oriented explanation and structure-oriented explanation.

Linz and Stepan's emphasize on the actor more than structure. They claimed that "three conditions - a lively and independent civil society; a political society with sufficient autonomy and a working consensus about procedures of governance; and constitutionalism and a rule of law - are virtually definitional prerequisites of a consolidated democracy. However, these conditions are much more likely to be satisfied where there are also found a bureaucracy usable by democratic leaders and an institutionalized economic society" (Linz and Stepan, 1996, p.20). Burton, Gunther and Higley claim that "consolidated democracies can be thought of as encompassing specific elite and mass features". Their main focus is on two factors: "shared consensus about role and codes of political conduct and the worth of political institutions among all important elite groups and factions, and extensive mass participation in the election and other institutional processes that constitute procedural democracy" (Burton, Gunther and Higley, 1992, p.3).

The level of economic development is one of the most widely discussed independent variables of the democratic consolidation. Lipset's popular proposition - the more well-todo a nation, the greater the chances that it will sustain democracy (Lipset, 1959, p. 75) has been tested in several ways. And it is also confirmed that "the chances for the survival of democracy are greater when the country is richer" (Przeworski and Limongi, 1997, p. 177). Comparing to the consolidation, the impact of economic development in the democratization is still less convincing. Another important factor is trust. It is often called social capital too. Paxton claimed that "the relationship between social capital and 


\section{Women Participation in Local Development: A Study of Kaski District}

democracy is reciprocal" (Paxton, 2002, p. 272). Along with these variables, the cultural factor, party system, economic crisis and so forth are widely discussed. In their popular article Gasiorowski and Power (1998) examined twenty-six structural variables that are related with the democratic consolidation. This study has summarized them into twenty-one variables.

Table 1: Structural variables that determine the democratic consolidation

\begin{tabular}{l|l|l|l|l|l}
\hline 1 & GDP & 2 & GDP per-capita & 3 & Workforce in industry \\
\hline 4 & University enrollment & 5 & $\begin{array}{l}\text { Secondary school } \\
\text { enrollment }\end{array}$ & 6 & Literacy \\
\hline 7 & Urbanization & 8 & Trade dependency & 9 & Religion (catholic) \\
\hline 10 & $\begin{array}{l}\text { Region } \\
\text { America) }\end{array}$ & 11 & Religion (Luslim) & 12 & Ethno-linguistic \\
\hline 13 & Inflation & 14 & Regime type & 15 & $\begin{array}{l}\text { Effective number of } \\
\text { political parties }\end{array}$ \\
\hline 16 & Military expenditure & 17 & $\begin{array}{l}\text { Military personnel } \\
\text { per capita }\end{array}$ & 18 & $\begin{array}{l}\text { Regional } \\
\text { democratization rate }\end{array}$ \\
\hline 19 & $\begin{array}{l}\text { Third wave } \\
\text { democratization rate }\end{array}$ & 20 & $\begin{array}{l}\text { Previous history of } \\
\text { democracy }\end{array}$ & 21 & $\begin{array}{l}\text { Number of prior } \\
\text { democratic transition }\end{array}$ \\
\hline
\end{tabular}

\section{Structural Factors and Nepali Loktantra}

The chapter is divided into two parts. First part examines the prediction of three major structural variables - economic modernization, regime type and party system - and Nepal's contemporary situation. Second part explores why the adoption of the structural variables in the Nepali context need modification. This part mostly discusses on the Nepali socioeconomic structure and nature of the Loktantra.

Przeworski and Limongi claimed that "democracy is more likely to survive in a growing economy with less than $\$ 1,000$ per capita income than in a country with an income between $\$ 1,000$ and \$2,000 that declines economically" (Przeworski and Limongi, 1997, p. 177). Nepal is in the risk zone according to this hypothesis. Nepal's GDP in fiscal year 2019-20 was \$ 1134 (Shrestha, 2021). Huntington $(1968,1971)$ also claimed that level of political institutionalization prior to the political change is key for the institutionalization of new regime. Otherwise, the result is political decay. He argued that:

If a society is to maintain a high level of community, the expansion of political participation must be accompanied by the development of stronger, more complex, and more autonomous political institutions. The effect of the expansion of political participation, however, is usually to undermine the traditional political institutions and to obstruct the development of modern political ones. Modernization and social mobilization, in particular, thus tend to produce political decay unless steps are taken to moderate or to restrict its impact on political consciousness and political 


\section{Women Participation in Local Development: A Study of Kaski District}

involvement. Most societies, even those with fairly complex and adaptable traditional political institutions, suffer a loss of political community and decay of political institutions during the most intense phases of modernization. (Huntington, 1968, p. 85-86)

The economic modernization-based hypothesis predicts negative future of democracy in Nepal. Huntington's thesis is particularly important. On the one hand, Nepali Loktantra could not give enough attention and effort on solving the problem of Nepali democracy that Nepal has experienced since 1990. The political culture, level of intraparty democracy, ineffectiveness of the democratically elected bodies and so forth remain unchanged. On the other hand, as seen above, Nepal attempted to establish a new political system with two characteristics: a democracy with minimalist standard and some characteristics of nonmajoritarian democracy. Though India remains the constant - exceptional - example of this kind of political regime (see: McMillan, 2008, Andeney and Wyatt, 2004, Moore, 1996), whether Nepal could achieve the democratic consolidation similarly is a question to be discussed continuously in future.

Second important factor needed to be discussed is the regime type. The impact of the parliamentarism in the consolidation of democracy in Nepal is hardly discussed. In 1980 s \& 90 s, there was a lively debate on the impact of the regime type in democratic consolidation. Juna Linz argued that the parliamentarism "provides a greater flexibility in the process of transition to any consolidation of democracy" (Linz 1985, p. 17). The main characteristics of parliamentary democracy which are conducive to the consolidation of the democracy are "relatively stable governments, a strong prime minister, who could guarantee responsible decision-making processes, strengthen the role of parties while assuring opportunities for genuine competition, and limit political fragmentation" (ibid). Mainwaring and Shugar, on the other hand, claimed that "other things being equal, presidentialism tends to function better where presidencies have weak legislative powers, parties are at least moderately disciplined, and party systems are not highly fragmented" (Mainwaring and Shugar, 1997, p. 449).

Two facts are particularly important while discussing the regime types and consolidation of the Nepali Loktantra. First, the struggle of the young Asian parliamentary democracy on consolidation (Humagain, et.al, 2020). Second and most important factor is nature of Nepali parliamentary democracy. In practice, the role of Nepali prime-minister is almost same like an executive president in a presidential system. Both formally and informally, the power is concentrated in the prime minister. Some important offices were brought under prime minister formally in 2018: Attorney General's office, National Investigation Bureau, Poverty Alleviation Fund, Development Board, National Planning Commission, National Development Council, National Vigilance Centre, Constitutional Council Secretariat, Department of Money Laundering Investigation, Central Bureau of Statistics and Department of Revenue Investigation under his office. Informally, PM office makes most if not all major decisions in the national issues. The role of the cabinet ministers and ministries are limited.

One of the major critics toward presidentialism was 'winner take all' system in the presidentialism (Horowitz, 1990). Nepali parliamentary democracy is also heading toward the same politics, which is ironic. The main goal of the adoption of the federal and parliamentary system is to avoid this issue rather than strengthening. The result is, opposite, 


\section{Women Participation in Local Development: A Study of Kaski District}

however. The development of this - comparatively new - political culture is another important subject of research in the future.

Political parties and party system could not become an attractive research question to the student of Nepali politics. For example, there were only few minor regional parties in Nepal until 2007. Not only the number of ethnic and regional parties increased but also their representation in the federal and provincial parliament increased rapidly. Fragmentation and unification of these parties become the regular features of Nepali politics. These questions, however, could not get enough academic interest (Humagain, et. al, 2019).

Similarly, there are many structural variables which need detail discussion in case of Nepal. Before that, we need particular concern in two questions. First, Nepal's socioeconomic structure. It is expected that four million people - the majority of them are young and educated - are in abroad. They are active tax payers and passive political participants. In this case, can we simply apply the structural variables that are based on the experience of industrialized countries?

Let's see an example of urbanization. In the industrial countries, urban cities are formed near the industrial areas. The factory workers and related workforce of the industries move to these newly established cities. Gradually, they bring their family members. They have regular income from the industries. They have very specific occupation and guarantee of the future. In case of Nepal, the urban cities are different. First and foremost, industrialization is not driving force of urbanization. Now it's time to ask an important question: can we expect same political attitudes and activities of the newly migrated people to Nepali cities like a middle class in industrialized countries?

This is one of the key questions that is to be discussed in detail in the future. We need to give special attention on two actor outcomes - absentee effect and class consensus - of the uniqueness our economic structure. On the one hand, a large majority of the young population, an active tax payer, are out of active politics, e.g., in voting, party committee and so forth. We need consideration on the direct effect of their absence in direct politics, during the period when they stay in abroad, as well as indirect effect - the gap in social impact on their participation and success in the politics. On the other hand, is there any fundamental impact of their different nature of their income, job and economic activities, after returning from abroad, on class consciousness and political participation is also a key question.

As discussed above, we cannot simply treat Nepali Loktantra as a procedural democracy or democracy with minimalist standard. It has some attempt to adopt some unique characteristics to solve the problems that were experienced in the past. One of the key examples is recently most contested article of constitution: article 76. Do we need a different operational definition of Nepali Loktantra or not? It is another important question to be discussed in future.

Theoretical and legal explanation alone, itself is not enough. One important question that we need to discuss in the background - as well as comparatively - regarding the study of Loktantra is: whether it is fundamentally different with Prajatantra that we practiced since 1990? Is there significant impact of different socio-economic condition of two periods? Does the adoption of federal structure bring visible change in the level of freedom, participation, political accountability and so forth? 


\section{Women Participation in Local Development: A Study of Kaski District}

To answer these questions and link these puzzles, we may get some theoretical and conceptual ideas from the academic studies that aim to analyze the different outcomes of modernization in Latin America in the 1960s-80s. When there was confusion on defining the nature of Latin American regime, Argentinean political scientist Guillermo O'Donnell called them bureaucratic authoritarianism and explained how the modernization resulted in the different regime outcomes in the Latin America (O'Donnell, 1988)). It is time for us to discover a national academic debate like this to both define our political regime and reasons behind its different practice in Nepal.

\section{Conclusion \& Discussion}

This study has three major findings. First, the macro-structural variables predict the pessimistic future of Nepali democracy. Second, defining Nepali Loktantra only as a procedural democracy or democracy with minimalist standard can't address all major characteristics. It is a democracy with minimalist standard with some major attributes of non-majoritarian democracy. Whether it has adopted some attributes of multiculturism is or not is still a subject for discussion. We need more rigorous discussion and definition on it. Third, related to second, if it is not simply a procedural democracy, we need a new analytical framework to examine the structural, institutional and cultural impacts on its level of institutionalization. This study attempts to explore the structural parts.

In the discussion part, I will present a more macro picture of the political economic approach to democracy. I will also present my personal idea that where we need to focus more in the future. Nepal is in the very uncommon path of global economic and political development. Except for a few cases, like our neighboring country India, very rare countries have simultaneously achieved economic development and institutionalization of the democracy. In most, if not all, cases the economic development achieved prior to the political development. In that sense, we need to pay special attention on the impact on the both sides: impact of democracy to development and impact of the development to democracy. As discussed above, we need a careful definition of Loktantra prior to this discussion.

Moreover, as seen above, both processes are different with most, if not all, advanced democracies. On the one hand, Nepal is in the path of socioeconomic transformation without significant impact of industrialization. We hardly have this kind of examples in the human history. There are some countries which became rich by selling natural resources. Neither Nepal falls in this category. Remittance from Nepali migrant workers around the globe - which covers near by 30 percent of GDP - is the main resource of development. Its impact on socioeconomic structure, class formation and consensus, political participation in individual and group are subjects for further discussion.

On the other hand, Nepal has adopted a unique democratic system after the failed practice of the procedural democracy for more than a decade since 1990. Both the nature of the new regime and its practicality are still contested subject. Not only defining it properly, but also developing a new analytical framework to examine the impact of structural, institutional and cultural variables on the state of Loktantra is another major area to be focused in the future.

Often, assuming Nepal as a small, underdeveloped and incomplete nation-state, the comparative studies in political economy have not received enough attention on state of Nepali democracy and its causes. It leads us to develop our own indigenous explanation and 


\section{Women Participation in Local Development: A Study of Kaski District}

prediction. It is not a serious problem. But, development of both indigenous explanation and explanation based on global tradition not only enriches our discussion but also provides several new options to improve and enhance the quality of democratic practices.

\section{References}

Adeney, K., \& Wyatt, A. (2004). Democracy in South Asia: Getting beyond the structureagency dichotomy. Political studies, 52(1), 1-18.

Bogaards, M. (2009). How to classify hybrid regimes? Defective democracy and electoral authoritarianism. Democratization, 16(2), 399-423.

Carothers, T. (2002). The end of the transition paradigm. Journal of democracy, 13(1), 5-21.

Collier, D., \& Levitsky, S. (1997). Democracy with adjectives: Conceptual innovation in comparative research. World politics, 49(3), 430-451.

Gasiorowski, M. J., \& Power, T. J. (1998). The structural determinants of democratic consolidation: Evidence from the third world. Comparative political studies, 31(6), 740-771.

Higley, J., Gunther, R., \& John, H. (Eds.). (1992). Elites and democratic consolidation in Latin America and Southern Europe. Cambridge University Press.

Horowitz, D. L. (1990). Presidents vs. parliaments: Comparing democratic systems. Journal of democracy, 1(4), 73-79.

Humagain, S., \& Seo, J. (2013). Failure to Democratize. The Korean journal of international studies, 11(1), 173-199.

Humagain, S., Aryal, T., \& Pandey, B. (2019). Three waves of (ethnic) party evolution in Nepal. South Asian studies, 24(4), 157-183.

Humagain, S., Subedi, G., \& Aryal, T. (2020). The perils of parliamentarism: Chasing the flows of the third wave of democratization in Asia. Journal of APF command and staff college, 3(1), 120-136.

Huntington, S. P. (1971). The change to change: Modernization, development, and politics. Comparative politics, 3(3), 283-322.

Huntington, S. P. (1993). The third wave: Democratization in the late twentieth century. University of Oklahoma press.

Hachhethu, K. (1997). Nepal in 1996: Experimenting with a coalition government. Asian Survey, 37(2), 149-154.

Kymlicka, W. (2005). Liberal multiculturalism: Western models, global trends, and Asian debates. Multiculturalism in Asia, 22-55.

Lijphart, A. (1985). Non-majoritarian democracy: a comparison of federal and consociational theories. Publius: The Journal of Federalism, 15(2), 3-15.

Lipset, S. M. (1959). Some social requisites of democracy: Economic development and political legitimacy. American political science review, 53(1), 69-105.

Journal of Political Science, Vol. 21, Special Issue, August 2021 [11-21] 


\section{Women Participation in Local Development: A Study of Kaski District}

Lawoti, M. (2008). Exclusionary democratization in Nepal, 1990-2002. Democratisation, 15(2), 363-385.

Linz, J. J. (1994). Democracy, Presidential or Parliamentary: Does It Make a Difference? Conference paper,

Linz, J.J., \& Stepan, A.C. (1996). Toward Consolidated Democracies. Journal of democracy $7(2), 14-33$.

McMillan, A. (2008). Deviant democratization in India. Democratization, 15(4), 733-749.

Moore, B. (1993). Social origins of dictatorship and democracy: Lord and peasant in the making of the modern world. Beacon Press.

O’Donnell, G. (1988). Bureaucratic authoritarianism. University of California press.

Parajulee, R. (2010). An experiment with a hybrid regime in Nepal (1990-2006). Journal of Asian and African studies, 45(1), 87-112.

Paxton, P. (2002). Social capital and democracy: An interdependent relationship. American sociological review, 67(2), 254-277.

Przeworski, A., \& Limongi, F. (1997). Modernization: Theories and facts. World politics, 49(2), 155-183.

Shrestha, P. M. (2021) Dip in per capita income challenge to Nepal's graduation to developing country status, Kathmandu Post (March 08, 2021) Accessed on July 27, 2021. Dip in per capita income challenge to Nepal's graduation to developing country status (kathmandupost.com)

Smooha, S. (2002). Types of democracy and modes of conflict management in ethnically divided societies. Nations and nationalism, 8(4), 423-431.

Schumpeter, J. (1950). Capitalism, Socialism and Democracy. 3rd ed. New York: Harper.

Van den Berghe, P. L. (2002). Multicultural democracy: can it work? Nations and nationalism, 8(4), 433-449. 